\title{
TORTS TO EXPECTANCIES IN DECEDENTS' ESTATES
}

\section{By Alvin E. Evans $\dagger$}

It is no part of the purpose of this paper to trace the confused history of the progressive extension of a tort remedy for the protection of interests in advantageous relations. Since Lumley v. Gye ${ }^{1}$ much progress has been made. Prospective advantages may be protected. ${ }^{2}$ There is no longer any doubt that a person cannot force an employer to dismiss an employee, in order to serve some ulterior and non-competitive purpose of that person. ${ }^{3}$ It seems that the expectancy of a beneficiary in the proceeds of an insurance policy upon the life of the insured is on the way toward protection against the wrongful interference of a third person. ${ }^{4}$ The question of the protection to be extended to expectancies in decedents' estates from fraudulent interference seems to occupy a twilight zone and is the subject matter of this paper.

In these expectancy cases the plaintiff may allege wrongful interference, to his injury ( $I$ ) in the procuring by the defendant of the execution of a will; (2) in the prevention of the execution of a will; (3) in causing the revocation or alteration of a will; (4) in the prevention of the revocation or alteration of a will ; (5) in the suppression or spoliation of a will; and (6) in obtaining by fraud an inter vivos conveyance from the source.

Possible remedies depending somewhat upon the type of interference are: ( $\mathrm{I}$ ) the raising of a constructive trust; (2) resistance to or setting aside of probate in the probate court; (3) setting aside of probate in equity; (4) a tort action for wrong to the plaintiff's expectancy or some substantially equivalent action at law or in equity.

Professor Gifford has said that "ejectment is a purely legal remedy and can be brought only by one having a legal right in the land

$\dagger$ A. B., 1898, Cotner University; A. M., I898, University of Nebraska; Ph. D., 1908, University of Michigan; J. D., Igr8, University of Michigan; Dean, University of Kentucky College of Law, since I927. Author: RoMan Law STudIES IN IIvY (I9I0), and of numerous articles in leading legal periodicals.

I. 2 E1. \& B1. 216, I18 E. R. 749 (Q. B. I853). See Walker v. Cronin, 107 Mass. 555 (I87I) ; Rice v. Manley, 66 N. Y. 82 (I876) (the contract protected need not be enforceable).

2. Carnes v. St. Paul Union Stockyards Co., I64 Minn. 457, 205 N. W. 630 (1925); Delz v. Winfree, 80 Tex. 400 , I6 S. W. III (I89r).

3. London Guarantee \& Accident Co. v. Horn, 206 I11. 493,69 N. E. 526 (1903) ; Moran v. Dunphy, 177 Mass. 485, 59 N. E. I25 (IgoI); Warschauser v. Brooklyn Furniture Co., 159 App. Div. 8r, I44 N. Y. Supp. 257 (2d Dep't I913). For the New York rule regarding closed shop and the procurement of the discharge of non-union workers, see National Protective Ass'n v. Cumming, I70 N. Y. 3I5, 63 N. E. 369 (Ig02), and Prosser, TORTS (194I) 976, IOOI, IO04.

4. Munroe v. Beggs, 9I Kan. 70I, I39 Pac. 422 (I9I4); Daugherty v. Daugherty, I52 Ky. 732, I54 S. W. 9 (I9I3). Contra: Alfsen v. Crouch, II5 Tenn. 352, 89 S. W. 329 (1905). See also Ross v. Wright, 286 Mass. 269, I9 N. E. 514 (I934), 98 A. I. R. 468 (r935). 
and yet it is the sole remedy against a devisee who by fraud in the inducement has persuaded a testator to devise land away from the heir." 5 Professor Warren, in an article on "Fraud, Undue Influence and Mistake in Wills," " does not touch upon the matter of a tort remedy at any length, commenting merely upon two cases. He raises the question, Is there any objection to allowing the victim an election whether to raise his claim in the probate court or later in a common law court? It is further suggested that if he may sue in tort, he may also waive the tort and sue in assumpsit for benefits received. Warren finds nine situations that arise: (I) cases where the probate court has jurisdiction and can do complete justice by refusing probate; (2) cases where claimant has been defrauded of a legacy where the probate court can afford no remedy; (3) cases of express trusts; (4) cases where there was an oral promise to hold in trust; (5) cases where the problem is one of construction; (6) cases of fraudulent revocation and prevention of republication; (7) cases of fraudulent prevention of revocation; (8) cases where the fraud of defendant has created a difficulty respecting proof; (9) cases of forged wills defrauding the next of kin. This article purposely omits some of the items suggested by Professor Warren, such as express trusts, oral promises to hold in trust, and questions of construction in general.

An initial proposition is that only probate courts have jurisdiction to probate wills and that a probate decree, like other judgments and decrees, is not subject to collateral attack. There is a disposition also on the part of courts to hold that if a claimant has an adequate remedy in the probate court, he should not first resort to a court of general jurisdiction.

\section{The Wrongful Procurement of a Will}

In Langdon v. Blackburn, ${ }^{7}$ the plaintiff sought to have the court declare the defendant a constructive trustee because of his having induced the decedent to sign a will at a time when he was unconscious and without testamentary capacity. The plaintiff alleged that she, sister and next of kin, was in a distant land and did not learn of the death of the decedent and the probate of his alleged will until after it was too late to contest it. The court held that this was an allegation of intrinsic and not extrinsic fraud, and so the plaintiff was making a collateral attack upon the probate decree. Since there is no jurisdiction in equity to set aside probate, a possible alternative would be a

5. Gifford, Will or No Will? The Effect of Frand and Undue Influence on Testamentary Instruments (I920) 20 CoL. L. REv. 862, 869.

6. (I928) 4I HaRv. L. REv. 309, 320-2.

7. I09 Cal. I9, 4I Pac. 814 (1895). 
tort action for the wrong done to the plaintiff's expectancy. This was not attempted. It appears that a petition in the probate court to set probate aside would be too late. It was assumed that a successful will contest and an action for tort to the expectancy as alternative remedies would reach substantially the same result. Not only is a will contest to be preferred ${ }^{8}$ in such case, but it is the logical remedy, inasmuch as the defendant's wrongful act is without effect if the contestant establishes his claim. Since a will contest was no longer possible, due to lapse of time, so also was an action in tort not available.

In Hall v. Hall ${ }^{9}$ the issues, as finally construed by the court, involved (I) a transfer procured to be made by the plaintiff's father to the defendants, co-heirs of certain property, for the purpose of defeating the plaintiff's expectancy, induced by a false representation made to the grantor respecting plaintiff's sanity; (2) a will procured to be made also by the plaintiff's father, by a similar fraudulent representation, giving property to the defendants which would otherwise have come to the plaintiff; (3) the false imprisonment of the plaintiff whereby the latter and his conservator were prevented from contesting probate of the will until the period for contest had elapsed. The defendant demurred.

Issue (I) is reserved, for the present. As to issue (2), it was held that the plaintiff could not proceed by a tort action without setting aside the probate decree for fraud. He could pray only for an injunction to restrain the defendants from setting up the probate decree as a bar to his assertion of an interest in the property or that they be ordered to account for the property as intestate assets. $\mathrm{He}$ could not pray for damages for a tort to his expectancy for this would be a collateral attack upon the probate decree. Yet the court asserted that the complaint contained sufficient allegations of fraud practiced on the court which would warrant a prayer for equitable relief but not for damages such as might ordinarily be assessed in an action at law. Such equitable relief does not result in a constructive trust but rather in setting aside a void decree. If the probate decree was void, as it clearly seems to have been, then the tort action was not a collateral attack and that particular ground for refusal of a common law action would seem to fail.

The court viewed the case as one calling for equitable relief only. The probate decree should first be set aside. When that has been done, defendant's wrongful act has failed of its purpose and the property passed to all the co-heirs, including the plaintiff. Thus, an action

8. See Axe v. Wilson, I50 Kan. 794, 96 P. (2d) 880 (1939).

9. 9I Conn. 5I4, I00 Atl. 44I (rgi6). 
in tort would fail for lack of damages. The fraud practiced here is such as would be denominated in California, extrinsic fraud. So far as appears, adequate relief could be achieved without resort to any other than the probate court.

In Seeds v. Seeds ${ }^{10}$ a father was alleged to have forged his wife's will, by which he acquired her property for himself and deprived the plaintiffs, her infant children, of their inheritance; procured it to be probated by perjured testimony; and prevented the plaintiff heirs from receiving notice of and contesting probate by accepting notice for them as their guardian. Defendant, transferee of the father, with notice, demurred to the petition and the court, on finding the above allegations to be admitted, declared him to be a constructive trustee. Since the allegations point toward the probate decree being void, a collateral attack in an action for damages would appear to be permissible also. The probate decree was void because the plaintiffs were deprived of their statutory right to be heard.

The problem of forged wills is an old one. Perhaps the most famous case is that of Broderick's Will. ${ }^{11}$ There the plaintiff petitioned the chancellor alternatively to set the probate of a forged will aside or to charge the defendants as trustees. The will had been probated eight years previously and it was held that the decree was res judicata. Inasmuch as the probate court of California, where the case arose, had power to revise its own decrees when they were tainted by mistake or fraud, equity could not revise them. Every objection here made could have been made in the probate court. The court also made this interesting observation: "In cases of fraud, equity has concurrent jurisdiction with a court of law but in regard to a will charged to have been obtained by fraud, this rule does not hold. It may be difficult to assign any very satisfactory reason for this exception. That exclusive jurisdiction over the probate of wills is vested in another tribunal is the only one that can be given." On the face of the pleadings no other result seems possible. No action in tort, however, for wrong to the plaintiff's expectancy seems to have been considered.

In Gaines v. Chew ${ }^{12}$ the heir charged that the true will had been suppressed and that an earlier revoked will had been probated fraudulently by the defendant's executors named in the revoked will. It was held that equity could not set aside the probate of a will and that relief was obtainable in the probate court. But it also held that the defendants could be required to answer touching the alleged spoliation of the later will. There is also a dictum to the effect that if the probate court

I0. I16 Ohio St. I44, I56 N. E. I93 (I927).

II. 2I Wall. 503, 22 L. Ed. 599 (U. S. I874).

I2. 2 How. 6Ig, II L. Ed. 402 (U. S. I844). 
should refuse a hearing because of defect of its power or lapse of time or on any other ground, the chancery court might require the defendants to consent to the proof of the later will. This seems to mean that the plaintiff could, in a chancery proceeding, prevent the defendants from taking advantage of the obstacles standing in the way of setting up the later will. The court said that the plaintiff could require the defendants to make explicit answers to the questions of suppression of the one will and the probate of the other. This holding seems to overlook the matter whether or not the probate decree was res judicata. The court did not hold the decree to be void. There are circumstances under which equity can give relief against a valid decree and apparently the circumstances here recited were regarded as sufficient if relief in the probate court should fail. ${ }^{13}$ It had previously been held in England that in the case of personalty, the issue of fraud or forgery in the procurement of a testament must first come before the ecclesiastical court and when land was the subject matter, the issue was for a common law court. ${ }^{14}$ But equity could direct that discovery be had. Some earlier cases of relief in equity were explained in Archer v. Mosse, ${ }^{15}$ on the ground that there had been no opposition to the prayer that the chancellor direct an issue devisavit vel non. This later view came down to American courts. Thus, in Armstrong v. Lear ${ }^{10}$ the Supreme Court held that equity had no jurisdiction where the will had not been probated. In Tarver $v$. Tarver ${ }^{17}$ the holding was similar, but the court somewhat inconsistently made an interpretation of the will and held that it was not conditional.

California considers that the raising of a constructive trust in such a case constitutes a collateral attack upon the probate decree. ${ }^{18}$ The issue of forgery could have been presented to the probate court for the purpose of preventing the proof of the will. California, however, will raise a constructive trust where the revocation of a will was fraudulently prevented. ${ }^{19}$ A remedy in the probate court is not available in such a case.

13. The court examined a number of early authorities. In some the chancellor held that he could pass in the first instance upon the validity of a will alleged to be forged or could direct an issue devisavit vel non. Goss v. Tracy, I P. Wms. 286, 24 E. R. 392 (Ch. I7I5); Welby v. Thornagh Prec. in Ch. I23, 24 E. R. 59 (I700); Roberts v. Winn, I Ch. Rep. 236, 2I E. R. 560 (I663); Maundy v. Maundy, I Ch. Rep. I23, 2I E. R. 526 (1638).

I4. Jones v. Jones, 3 Meriv. I6r, 103 E. R. 62 (Ch. I8I7) ; Anon., 3 Atk. I7, 26 E. R. 813 (Ch. I743) ; Bennet v. Vade, 2 Atk. 324. 26 E. R. 597 (Ch. I742); Webb v. Claverden, 2 Atk. 424, 26 E. R. 656 (Ch. I742) ; Archer v. Mosse, 2 Vern. 8, 23 E. R. 618 (Ch. I686).

I5. 2 Vern. 8, 23 E. R. 618 (Ch. 1686).

I6. I2 Wheat. I69, 6 L. Ed. 589 (U. S. I827).

17. 9 Pet. I74, 9 L. Ed. 9 I (U. S. I835).

I8. Tracy v. Muir, I5I Cal. 363, 90 Pac. 832 (1907).

19. Brazil v. Silva, I8I Cal. 490 , I85 Pac. I74 (Igrg). 


\section{Frustration of Testamentary Execution}

Inasmuch as the probate court cannot grant relief where the testator has been prevented from executing a will, the plaintiff would be without remedy if a decree of distribution following a grant of letters of administration were res judicata. May plaintiff have a choice whether to proceed to set up a trust or to sue at law for tort? In the first place, it is apparent that the influence used to prevent the testator from benefiting a particular legatee must be undue in order to be actionable. So in Marshall $v$. De Haven ${ }^{20}$ the plaintiff brought trespass against the defendant for inducing the decedent not to change his will in the interest of the plaintiff. He alleged that the defendant paid a large sum of money to prevent an alteration in the will beneficial to the defendant, but no fraud or undue influence was directly charged. Under such pleadings no trust could be declared. In Kansas the draftsman fraudulently omitted from the will a legacy for the plaintiff which he had been directed by the testator to insert. ${ }^{21}$ The court refused to make the beneficiary heir-legatee a trustee because she was ignorant of the fraud, although her husband was a party to it. While there seems to be no adequate reason why a trust should not be raised to prevent the heir or legatee from being unjustly enriched, a tort action would not lie against her. One wonders, however, why the alternative remedy by way of suit against the draftsman and the colluding husband was not resorted to. Such an action was not brought. The plaintiff asked in the alternative for reformation of the will or for a constructive trust. Even though a court may refuse to raise a constructive trust based upon unjust enrichment, the analogies favor an action for damages against the wrongdoer.

In Ohio a tort action has been denied. Thus, in one case the defendant had prevented the calling of attesters. ${ }^{22}$ The plaintiff's prospect was held not to be of such legal importance as to warrant the protection of it, inasmuch as he had no vested interest in the decedent's property. His right was not considered equal to rights of another character, such as those in prospective contracts. It is this refusal to follow the contract analogy of the interference with contract that seems wholly objectionable. Ohio, however, as will later be seen,

20. 209 Pa. I87, 58 Atl. I4I (1904).

2I. Dye v. Parker, I08 Kan. 304, I94 Pac. 640, I95 Pac. 599 (I921).

22. Cunningham v. Edward, 52 Ohio App. 6r, 3 N. E. (2d) 58 (1936), 5 FordHaMr L. REv. 5I4. In Dixon v. Olmius, I Cox Eq. 4I4 (1787), the heir by force and fraud had prevented the testator from making (republishing) his will, whereby plaintiff, the intended devisee, was deprived of his devise. A constructive trust was declared. See 3 ScotT, Trusts (I939) $\$ 489.4$. 
allows a tort action for interference with one's prospect in a will already executed. ${ }^{23}$

On the other hand, protection has been extended in other states to this interest of expectancy. Thus, in Massachusetts ${ }^{24}$ the plaintiff was held to state a cause of action in tort when he alleged that the defendant, the confidential adviser of the testator, induced the latter to draw a codicil which was and was intended by the defendant to be invalid, in order to defraud the plaintiff of property he would otherwise have received. So in Bohannon v. Wachovia Bank \& Trust Co. ${ }^{25}$ the plaintiff alleged that the decedent had formed the fixed purpose of giving the former a share in his estate and that the defendant, either by preventing the execution of a will beneficial to the plaintiff or by causing a like will to be revoked, had defrauded him. He sought an order to discover the facts, which was granted on the defendant's motion to vacate the order; the plaintiff was held to have stated a cause of action in tort.

Thus, it is seen that the inquiry in such cases is coming to be not, Was the plaintiff vested with an interest in the property about to be left to him, but rather, Was there a right to have his prospect not interfered with fraudulently which should be protected? There appears to be no adequate reason why the plaintiff should not have alternative remedies, one at law for tort to his expectancy or one in equity to raise a trust.

\section{Inducing the Revocation or Alteration of Wills}

The leading case is Allen v. McPherson. ${ }^{26}$. A will and several codicils had been offered for probate in the ecclesiastical court. The last codicil revoked the provisions of a prior will and codicils by which large bequests had been made to the plaintiff. The latter asked to have the defendant declared a trustee and alleged that the last codicil of the revoking will had been procured by the undue influence of the residuary legatee. It was held that equity had no jurisdiction in the matter for the reason that the ecclesiastical court had already investigated the same charge and found it to be untrue. The plaintiff's remedy was by way of appeal only.

The probate court has jurisdiction to determine whether a given will had been revoked or altered by fraud or otherwise and its decree on that issue is res judicata. If it should find that the revocation was fraudulent, it would be able to set up the original will. Suppose, how-

23. Morton v. Petitt, I24 Ohio St. 24I, I77 N. E. 59I (I93I).

24. Lewis v. Corbin, 195 Mass. 520, 8 I N. E. 248 (1907).

25. 2ro N. C. 679, I80 S. E. 390 (I936). See Note (I937) 22 CorN. I. Q. 440.

26. I H. L. Cas. Igr, 9 E. R. 728 (Ch. I847). 
ever, that the defendant has forged his own name as a beneficiary of a legacy in substitution for the plaintiff. The court could refuse probate of that part of the will but that would not avail the plaintiff in any way. Hence, it would be better to probate the will as an entirety and have the defendant declared a trustee. This would probably be a more adequate remedy than a tort action would be, ${ }^{27}$ but the latter action should be available.

Ohio adopted the theory of Allen $v$. McPherson, supra, under circumstances which were only formally similar. Thus, in Petitt $v$. Mor$\operatorname{ton}^{28}$ a will benefiting plaintiff was revoked by a subsequent forged will. This fact, however, unlike that in the English case, was not discovered for a period of eight years. Consequently, the issue of forgery was not passed upon by the probate court. It was then too late to ask the probate court to set the probate aside. The plaintiff asked that the defendant be declared a trustee. The reason given for the refusal was that a claimant under an unprobated will can show no interest. . It is appropriate that the plaintiff, who claims under a will, should be required to establish his claim in the way provided by law. The issue of forgery, however, had never been passed upon and no finding theregn by the probate court was implied or necessary. A right of action in tort was not set up in the pleadings. The plaintiff was thus fraudulently misled into believing that the will was valid. ${ }^{29}$ Under such circumstances some courts hold that equity should give relief, since it is impossible to have a remedy in the probate court, due to lapse of time. This much is implied, if not actually expressed, in Gaines v. Chew, supra. Why should not an action in tort also be available?

In New York, Hutchins v. Hutchins ${ }^{30}$. (earlier than Lumley v. Gye) held that inasmuch as the plaintiff had no interest in the decedent's property, he could not have an action in tort for a wrong to his expectancy. The plaintiff's father had made a will devising a farm to the plaintiff. The defendants, being heirs, fraudulently induced the father, a feeble old man, to make another will which omitted the plaintiff as a beneficiary. A later federal case, however, intimates that a tort cause of action can be stated ${ }^{31}$ and the plaintiff was merely required to make his allegations of fraud more specific. This holding is possibly questionable, however, inasmuch as it is not clear that there

27. Marriot v. Marriot, I Strange 666, 93 E. R. 770 (K. B. I726).

28. 28 Ohio App. 227 , I62 N. E. 627 (Ig28). For the subsequent disposition of this case, see Morton v. Petitt, I24 Ohio St. 24I, I77 N. E. 59I (I93I), and discussion infra.

29. Restatement, JUDGMENTS (I942) § I2I.

30. 7 Hill IO4 (N. Y. I845).

31. Murphy v. Mitchel1, 245 Fed. 2 I9 (N. D. N. Y. I9I7). 
was anything to prevent the filing of a petition to set aside the probate of the revoking will.

Massachusetts and North Carolina seem to approve of the position suggested above, that a tort action should lie. Thus, in May $v$. $W_{o o d}{ }^{32}$ an action in tort was brought for maliciously inducing the testatrix to discharge the plaintiff from his employment and for causing the testatrix to revoke a legacy to the plaintiff. The court held that the plaintiff should make his allegations of fraud more specific. Chief Justice Holmes was of the opinion that they were already adequate. In Dulin v. Bailey, ${ }^{33}$ the plaintiff recovered in tort for the spoliation by the defendant whereby the latter removed the part of the will beneficial to the former. It was held that the plaintiff was not required to have the provision for his legacy probated and this action was not an attack upon the probate record.

It appears then that in England no tort action is available if the specific fraud was made an issue in the probate proceedings. In Massachusetts, North Carolina, and perhaps New York, an action in tort is available assuming no issue of fraud was made in the probate proceedings. In Ohio a constructive trust is not a permitted remedy unless the plaintiff is an heir, but a tort remedy probably is allowed.

\section{Frustration of Testamentary Revocation}

Many of the cases, especially the earlier ones, are concerned with the question whether a will directed by the testator to be destroyed but which was fraudulently preserved, could be regarded as revoked. No other remedy seems to have been considered in the cases. Generally it has been held that some revocatory act is required by statute in addition to the direction to destroy in order to accomplish a revocation. ${ }^{34}$ In some states, under the statutes then prevailing, the will was regarded as revoked. ${ }^{35}$

In Vermont a dictum says that equity will interfere to defeat the fraud of the preserver but whether by constructive trust, by refusing probate, by declaring a revocation in equity, by setting the will

32. I72 Mass. Ir, 5 I N. E. I9I (I898).

33. 172 N. C. 608,90 S. E. 689 (Igr6).

34. Bohleber v. Rebstock, 255 I11. 53,99 N. E. 75 (I9I2); Thomas v. Briggs, 98 Ind. App. 352, I89 N. E. 389 (1934); Axe v. Wilson, I50 Kan. 794, 96 P. (2d) 880 (1939) ; Mundy v. Mundy, 2 McCart. 290 (N. J. Eq. 1858) ; Leaycraft v. Simmons, 3 Bradf. 35 (N. Y. 1854) (civil law rule contra); Hise v. Fincher, to Ired. I39 (N. C. 1849); Kent v. Mahaffey, to Ohio St. 204 (1859); Means v. Moore, 3 McCord 282 (S. C. I825); Boyd v. Cook, 3 Leigh 32 (Va. I83I); Williams v. Williams, 33 Beav. 306, 55 E. R. 385 (1863).

35. Card v. Grinman, 5 Conn. 164 (1823) (court admits the evidence of fraud which seems to indicate that revocation in this way is possible). In North Carolina [see Hise v. Fincher, Io Ired. I39 (N. C. I849)], though such evidence was admitted, the revocation was not admissible. See Smiley v. Gambill, 2 Head I64 (Tenn. I863). 
aside, or in some other way is not indicated. ${ }^{36}$ A Kentucky dictum favors a constructive trust. ${ }^{37}$ Concededly the probate court has no power to raise it ${ }^{3 s}$ and in order to set one up in equity, it would be necessary to prove clearly that the will probated was fraudulently preserved and did not express the wishes of the decedent. ${ }^{39}$ California will award a remedy by raising a trust. ${ }^{40}$ The probate decree is not res judicata of the fraud issue and the action is not a collateral attack. Florida will not do so, ${ }^{41}$ because the plaintiff has no sufficient interest in the property to warrant it. In such a case, however, a tort action should lie, not because plaintiff had a present interest in the property but rather because he had a provable expectancy and a cause of action arose for wrongful interference with it. No case has been found, however, of this type where an action in tort was brought.

\section{The Suppression and Spoliation of Wills}

Some of the possible remedies for spoliation or suppression of a will may be (a) to resist in the probate court the probate of a conflicting will and to admit proof of the suppressed will by such evidence as may be available; (b) to sue in tort; (c) to ask that a trust be raised; (d) to bring a bill in equity to set up the spoliated will.

In Washington it was held that the plaintiff must offer the suppressed will for probate within the time limited for probate. Any action for an accounting and to impose a trust upon the suppresser was regarded as an attack upon the provisions of the probate decree. ${ }^{42}$ The plaintiff need not prove the suppressed will in its entirety but only his own interest. Here a tort action might well be preferable because the evidence of the suppression and the disadvantage to the plaintiff might well be established more easily in a tort action than in a probate proceeding. In Massachusetts also, as held in Thayer $v$. Kitchen, ${ }^{43}$ a general demurrer in a tort action is to be sustained where the plaintiff still has recourse to probate. This case, however, is not authority for the proposition that a tort action would not lie if the time for probate had elapsed. It would seem that if there is nothing

36. Blanchard v. Blanchard, 32 Vt. 62 (I859). $\$ 489.2$.

37. Gains v. Gains, 2 Marsh. 609 (Ky. I820). See 3 Scotr, Trusts (I939)

38. Graham v. Burch, 47 Minn. I7I, 49 N. W. 697 (I89I).

39. Ibid.

40. Brazil v. Silva, I8I Cal. 490, I85 Pac. I74 (I9I9).

4I. Moneyham v. Hamilton, I24 Fla. 430, I68 So. 522 (1936) (the court distinguishes between a frustration of an attempt to revoke and the prevention of the carrying out of an intent to revoke).

42. Davis v. Seavey, 95 Wash. 57,163 Pac. 35 (1917).

43. 200 Mass. 382, 86 N. E. 952 (I909). 
to prevent probate, it would be better to do so than to sue in an ordinary action at law. ${ }^{44}$

The plaintiff's position, under the circumstances in which he finds himself, is improved by the presumption indulged against a despoiler. Strict proof of the contents of the will is not required and the evidence may sustain the plaintiff's case, although it be vague and uncertain. ${ }^{45}$ A similar consideration is shown to the plaintiff in suits involving commercial transactions, even to the extent that, having destroyed the evidence, the defendant is presumed to admit the plaintiff's allegations. ${ }^{46}$ As against the despoiler of a will, the legatee has been allowed to prove his own interest only, in a will contest. He may introduce the statements of the decedent in proof of his claim and the court will presume that a wilfully destroyed will was duly executed. ${ }^{47}$ Under the older practice that the validity of a devise was finally to be determined in an action at law, two witnesses were not nécessary to establish the will, as they are for proving a will in probate court ${ }^{48}$ and a surrogate finding against a devise did not bind a law court. ${ }^{49}$

Although the chancellor is usually held to have no jurisdiction to set up an unprobated will, ${ }^{50}$ yet a remedy closely similar was adopted in a few cases. Thus, a bill to compel a suppresser to produce the will, or in the alternative to hold for the plaintiff the land involved; to require the execution of a deed to the latter and to enjoin the defendant from asserting a claim to the property has been sustained. ${ }^{51}$ This method is not unlike the setting up of a trust. So in England the court has, at times, decreed that the plaintiff may hold the property until the defendant produces the will ${ }^{52}$ and a bill to pay a legacy has been sustained in equity, ${ }^{53}$ although the will had not been probated. The latter cases are somewhat analogous to those which hold strongly

44. Cf. Axe v. Wilson, 150 Kan. 794, 96 P. (2d) 880 (I939).

45. Anderson v. Irwin, Ior I11. 4II (I882).

46. Thompson v. Thompson, 9 Ind. 323 (I857) ; Pomeroy v. Benton, 77 Mo. 64, 86 (I882) ; Armory v. Delamirie, I Strange 505, 93 E. R. 664 (K. B. 1722) (the truth of the plaintiff's evidence is presumed to be admitted because of the defendant's fraud in destroying the evidence). See 2 WIGMORE, EvIDENCE (3d ed. 1940) $\$ \$ 278,29 \mathrm{I}$, and $9 \mathrm{id}$. $\$ 2524$ and citations there made, and cases cited in notes 26-30 supra.

47. Lane v. Cole, I2 Barb. 680 (N. Y. I852) ; Davis v. Lovell, 4 M. \& W. 678, I50 E. R. 1593 (Ex. I839). Cf. Robinson v. Trull, 4 Cush. 249 (Mass. 1849); In re Pierce, I63 N. C. 247,79 S. E. 507 (I9I3).

48. Cunningham v. Edward, 52 Ohio App. 6r, 3 N. E. (2d) 58 (r936).

49. See Allen v. Grant, I83 App. Div. 555, I7I N. Y. Supp. 769 (I9I8).

50. McDaniel v. Pattison, $98 \mathrm{Cal}$. 86, 27 Pac. 65I, 32 Pac. 805 (I893) ; Morningstar v. Selby, I5 Ohio 345 (I846); Myers v. O'Hanlon, I3 Rich. I96 (S. C. I86I). Contra: Buchanan v. Matlock, 8 Hump. 390 (Tenn. I847).

5I. Bailey v. Stiles, I Green 220 (N. J. Eq. I839).

52. Hampden v. Hampden, 3 Brown 550, I E. R. I492 (H. L. 1709), and see Dalston v. Coatsworth, I P. Wms. 73I, 24 E. R. 589 (Rolls Ct. I72I).

53. Tucker v. Phipps, 3 Atk. 359, 26 E. R. 1008 (Ch. I746). 
against the despoiler. So in Vermont equity decreed the payment of legacies in a will fraudulently suppressed and never probated. ${ }^{54}$

Other states have held that a tort action may be sustained, though the suppressed will is never offered for probate. ${ }^{55}$ In Ohio the court believes that a stronger case is made out for the victim of a spoliated will than for one who merely claims that the will in his favor was never made, due to the fraud of the defendant. ${ }^{56}$ A constructive trust was denied in the latter situation, but no action in tort was attempted. It is agreed that a stronger interest is created, one in the nature of a gift on a condition subsequent, where the will has been executed but suppressed, than the interest arising where no will has ever been made. The plaintiff, besides damages, may recover his costs, expenses for proving the spoliation of the will, for his time, and other losses.57 Several cases hold that an offer of probate is not a prerequisite to an action in tort or to one for setting up a trust. ${ }^{58}$ The conclusion seems to be, by weight of authority, that if $a$ destroyed or suppressed will can be probated, it should be, but if not, there is no bar to a tort action.

It has been suggested that an action for damages for loss of evidence may be available in these cases. If the plaintiff summons a witness in a common law action who fails to appear, without cause, he may be liable for all the damages sustained by the former. It has even been held that the plaintiff need not prove that he had a good cause of action in the case for which the defendant was subpœnaed, though some courts would probably hold that the plaintiff should make out a prima facie case for recovery in the other action. ${ }^{59}$ So, in Dulin $v$. Bailey, ${ }^{60}$ the plaintiff was permitted to prove his right to a legacy in a tort action by only one witness, whereas two are required to prove the contents of a will offered for probate. ${ }^{61}$ The (1849).

54. Mead v. Langdon (i834), referred to only in Adams v. Adams, $22 \mathrm{Vt} .50,59$

55. Creek v. Laski, 248 Mich. 425, 227 N. W. 8I7 (r929); Dulin v. Bailey, I72 N. C. 608,90 S. E. 689 (I9I6); Morton v. Petitt, I24 Ohio St. 24I, I77 N. E. 591 (I93I).

56. Cunningham v. Edward, 52 Ohio App. 6I, 3 N. E. (2d) 58 (I936).

57. Taylor v. Bennett, I Ohio C. C. 95 (I885).

58. See In re Estate of Lambie, 97 Mich. 49,56 N. W. 223 (I893); Dulin v. Bailey, 172 N. C. 608 , 90 S. E. 689 (I916) (defense was that the plaintiff should first offer will for probate); Mead v. Langdon (I834), referred to only in Adams v. Adams, 22 Vt. 50, 59 (1849) ; Tucker v. Phipps, 3 Atk. 359, 26 E. R. I008 (Ch. 1746); Hampden v. Hampden, 3 Brown 550, I E. R. I492 (H. L. I709).

59. Lane v. Cole, xz Barb. 680 (N. Y. I852); Davis v. Lovell, 4 M. \& W. 678, I50 E. R. I593 (Ex. I839). Cf. Robinson v. Trull, 4 Cush. 249 (Mass. I849); In re Pierce, I63 N. C. 247,79 S. E. 507 (1913). Respecting proof of revocation appearing in a lost will by fewer than the statutory number required to probate a will, see Evans, Testamentary Revocation by Subsequent Instrument (I934) 22 KY. L. J. 469, 497.

6o. I72 N. C. 608 , 90 S. E. 689 (1916).

6r. See Creek v. Laski, 248 Mich. 425, 227 N. W. 8I7 (I929), (I930) 30 Cor. L. Rev. 409, (I930) I4 MrNN. L. Rev. 704; Tucker v. Phipps, 3 Atk. 359, 26 E. R. Io08 (Ch. I746) (bill in equity for same purpose). 
plaintiff, in such a case, may prove his own legacy without proof of entire will, though generally to procure probate, proof of the entire contents of a lost will is likely to be required. When the claimant raises an issue as to his interest in a lost and unprobated will, the matter of the right to evidence becomes of great importance. Thus, if the plaintiff is required to probate the will in order to establish his claim, he may fail. ${ }^{62}$ Equity cannot order the will to probate. Even if the will could be proved, the question may arise whether the procedure to probate it would not be an attack upon a prior final decree of distribution. ${ }^{63}$ It is not clear why the plaintiff should not recover damages for the destruction of the will ${ }^{64}$ and his consequent inability to probate it or even raise a constructive trust in the proper case. ${ }^{65}$ Recovery has been allowed for the additional costs and expense of proving a will cau'sed by defendant's wrongful suppression. ${ }^{68}$

\section{Fraudulent Inter-Vivos Conveyances}

As noted above, one aspect of Hall v. Hall ${ }^{67}$ involved an allegation that the defendants had conspired to have the decedent father transfer to plaintiff's co-heirs certain property, thus preventing the plaintiff from receiving his portion of it by inheritance or by will. The demurrer to the petition admitted this allegation to be true. The court held that the plaintiff's expectation was not a legal property interest and that the plaintiff had no cause of action. Thus, here again is a clear refusal to extend to an expectancy of inheritance the protection which has come to be extended in a wide field of transactions. ${ }^{68}$

Somewhat similar is the case of Ross $v$. Wright. ${ }^{69}$ The decedent had directed the defendant, his son, the officer of a business trust, charged with the duty of making all transfers, to transfer fifty shares of his stock in the trust to plaintiff, decedent's granddaughter. The defendant refused to do so save on condition that certain other shares should also be assigned to himself and his sisters. The decedent died soon thereafter, before being able freely to complete the gift. The defendant demurred to these allegations. It was held that the plaintiff

62. McDaniel v. Pattison, 98 Cal. 86, 27 Pac. 65I, 32 Pac. 805 (1893); Thayer v. Kitchen, 200 Mass. 382,86 N. E. 952 (I909).

63. Held not in Walker's Estate, I60 Cal. 547, 550, II7 Pac. 5Io, 5II (IgII).

64. See Dulin v. Bailey, I72 N. C. 608, go S. E. 689 (IgI6).

59 ( 1849 ).

65. See Mead v. Langdon (I834), referred to only in Adams v. Adams, 22 Vt. 50,

66. Taylor v. Bennett, I Ohio C. C. 95 (1885).

67. 9I Conn. 5I4, I00 Atl. 44I (I9I6).

68. See Note (IgI7) 27 YALE I. J. 263. Cf. In re Lage, Ig F. (2d) I53 (N. D. Iowa 1927), holding that the expectancy under a binding contract does not pass to the trustee in bankruptcy of the expectant devisee.

69. 286 Mass. 269, I90 N. E. 5I4 (I934), I4 B. U. L. REv. 860. See Notes (I935) 48 HaRv. I. REv. 984, (I934) Io Notre DaMe Lawyer 94. 
had no cause of action because the defendant was under no duty to the plaintiff to act and the refusal to act did not involve fraud, duress or undue influence.

The court was influenced by the proposition that the conduct of the defendant was negative. . The distinction between nonfeasance and misfeasance, however, is often blurred by the situation. The refusal to act by one who alone has the legal power to accomplish a certain result is far different from such a refusal when other avenues are readily open to the petitioner. In this case it amounts to duress, which prevents the decedent from carrying out his purpose. The plaintiff had an expectation of a gift and its consummation was prevented by the interference of the defendant. This interference is duress in negative form.

Did the defendant owe any duty to the plaintiff? It was his obligation to perform this service and it is arguable, therefore, that the trust estate would have been chargeable for the loss to the plaintiff if a suit had been properly brought against the trustee. ${ }^{70}$ The defendant knew that his conduct would cause the plaintiff the loss of a gift save on the performance of a condition which he had no right to impose. It seems that under these circumstances he owed a duty to the plaintiff. ${ }^{71}$ Thus, if the plaintiff had alleged a sale to herself of the stock, the contract to be performed only on the transfer being made on the books and had further declared that the defendant had refused to make the transfer for the purpose of preventing the performance of the contract, she would have stated a cause of action. The conduct of the defendant was analogous to a conversion of the stock. ${ }^{72}$ It cannot be denied that the defendant was the active cause of the plaintiff's loss. "When the agent knowingly fails to perform, he is consciously subjecting a known person to a known danger." 73

\section{Intrinsic and Extrinsic Fraud}

The granting of relief from probate decrees is often made to depend upon the question whether the fraud practiced by the beneficiary is of the type so-called intrinsic or, on the other hand, is described as extrinsic. Thus, in La Salle v. Peterson, ${ }^{74}$ the court declared that fraud such as was required to set aside a decree must be extrinsic or collateral to the questions determined in the action, that a decree would

70. See Erie R. R. v. Stewart, 40 F. (2d) 855 (C. C. A. 6th, 1930).

7I. See 4 Restatement, Torts (r939) § 87ob.

72. See I Restatement, Torts (I934) § 223 .

73. Seavey, The Liability of an Agent in Tort (1916) I So. L. Q. I6, 36. Cf. 2 RESTATEMENT, ToRTS (I934) $\$ 353$ and caveat thereto.

74. 220 Cal. 739, 32 P. (2d) 6r2 (1934). 
not be annulled merely because it had been obtained by forged documents or perjured testimony. If the plaintiff had an opportunity to make the truth appear at the trial, there could be no relief merely because he was overborne by perjured testimony or his inability to present the true facts. In Tracy $v$. Muir, ${ }^{75}$ the heir filed a bill to make the executor a constructive trustee. She alleged that the will was a forgery and that probate had been obtained by perjured testimony through a conspiracy and that certain of the conspirators were on the jury which found for the will. The plaintiff was domiciled in Hawaii and had no knowledge of the proceedings. Notice of probate had, however, been given in accordance with the statute. The fact that the plaintiff was not a party prevented her from being bound by the decree but she was held to be bound by a statute making probate conclusive after a year. ${ }^{76}$

On the other hand, in another case ${ }^{77}$ the executrix was the widow of the decedent and also the mother of a child not his child. In her petition for probate she alleged that the child was decedent's also. She obtained a decree giving a share of the property to her child by false evidence. The other infant children did not have their day in court. It was held that the decedent's infant children had not had their day in court and that this concealment, while not sufficient to set the decree aside, was a sufficient basis for a constructive trust. In Weyant v. Utah Savings \& Trust Co. $^{78}$ the decedent had abandoned his wife and children, had eloped with the defendant and had lived with her under a fictitious name for many years. On his death, the defendant was named administratrix and notice of proceedings was given, in accordance with the statute, but under the assumed name, which afforded no means of knowledge to the deserted family. Here the plaintiffs, on discovery of the facts, were successful in setting aside the probate proceedings after it was too late to proceed in the probate court. The remedy was held to be a direct attack based on extrinsic fraud. ${ }^{79}$

75. I51 Cal. 363, 90 Pac. 832 (I907). See also Langdon v. Blackburn, Io9 Cal. I9, 4I Pac. SI4 (I895) (the plaintiff lived in a remote district, will forged, no allegation of failure of notice) ; Stowe v. Stowe, I40 Mo. 594, 4I S. W. 95 I (I897). Sometimes, also, plaintiff seeks, in effect, to have a court of equity probate the will; see McDaniel v. Pattison, 98 Cal. 86, 27 Pac. 65I, 32 Pac. 805 (I893). See also Davis v. Seavey, 95 Wash. 57, I63 Pac. 35 (I9I7).

76. See Restatement, Judghents (I942) § I26 (2) (a), (b), and (d).

77. Sohler v. Sohler, I35 Cal. 323, 67 Pac. 282 (Ig02). Why was the decree of distribution not void on this showing?

78. 54 Utah I8I, I82 Pac. I89 (I9r9). See also Baker v. O'Riordan, 65 Cal. 368, 4 Pac. 232 (I884) ; Langdon v. Blackburn, rog Cal. I9, 4I Pac. 8I4 (I895), referred to in notes 7 and 75 supra; Hall v. Hall, 9r Conn. 514, I00 Atl. 44I (I9I6), discussed at page ISg supra.

79. For reasons for refusal to use these terms, see REstatenrent, Judgrients (1942) § II $8 b$. 
In Benson v. Anderson ${ }^{80}$ the petition showed that on the death of the husband, his wife legally inherited one-half of the land in the estate. The probate court, however, erroneously decreed all the property to the decedent's brother. After the time for appeal had expired, a bill was filed by the widow to set aside the decree. The decree was annulled and a new distribution was made. The widow was Danish and had no knowledge of English and so it might be said that she had no notice. ${ }^{81}$

Thus, it appears that a probate decree may be directly assailed if those disappointed had no reasonable opportunity to be heard. ${ }^{82} \mathrm{Re}-$ lief will not, however, be granted where the decree is merely erroneous, or inequitable, or was obtained by false or perjured testimony, ${ }^{83}$ or where the complainant had no actual knowledge of the proceedings, but there was an opportunity to be heard, as the statute requires.

\section{Attack upon the Probate Decree}

A serious issue is the question how the remedy in tort for damages to plaintiff's expectancy is affected by a prior probate decree.

(a) It seems to be granted that if a remedy is provisionally available both in the probate court and in a law or equity court, the former is to be preferred. Thus, where plaintiff claims that a will has been wrongfully procured, he should preferably contest it rather than sue in tort. Much the same result, however, would accrue if plaintiff should be successful, whichever course were followed. ${ }^{84}$ So also if the plaintiff voluntarily abandons a contest proceeding which he has begun, he is later prohibited from substantially setting aside the decree in equity by setting up a constructive trust. ${ }^{85}$ Where the will has been suppressed or destroyed, it may still be probated, if the evidence was not destroyed. ${ }^{86}$ This leaves the question still open for an action in tort if the plaintiff should fail in the probate court because of the destruction of evidence by the defendant. Where the plaintiff claims the defendant's legacy has been forged, he should establish the fact at probate and not allow the entire will to be proved and contemplate thereafter a correction of the finding in equity. ${ }^{87}$ So a payment to the defendant, as executrix, under a probated will cannot be assailed in a

8o. Io Utah 135, 37 Pac. 256 (1894).

8I. Case is disapproved of in Sohler v. Sohler, I35 Cal. 323, 67 Pac. 282 (Ig02).

82. See REsTATEMENT, Judgments (I942) \$§ II8-i24.

83. See id. § I26.

84. Axe v. Wilson, I50 Kan. 794, 96 P. (2d) 880 (I939).

85. Tracy v. Muir, I5I Cal. 363, 90 Pac. 832 (rgo7).

86. Thayer v. Kitchen, 200 Mass. 382, 86 N. E. 952 (1909) ; Davis v. Seavey, 95 Wash. 57, I63 Pac. 35 (I9I7).

87. Plume v. Beale, I P. Wms. 388,24 E. R. 438 (Ch. I7I7). 
different action ${ }^{88}$ and a finding as to heirship precludes omitted heirs from attacking the title to land in equity. ${ }^{89}$

(b) Equity has often declared a constructive trust based on the promises of a devisee or legatee to hold for another ${ }^{90}$ and upon the promises of an heir to hold for a third person in consideration that the decedent make no will. ${ }^{91}$ The probate court could give no remedy in such cases. The issues considered here arise on unperformed promises, and are appropriately viewed as trust problems.

(c) There should be no difficulty in raising a constructive trust in the case of the frustration of a revocation, at least where the one who intervenes is the beneficiary, ${ }^{92}$ though it has been held otherwise in Florida. ${ }^{93}$ The probate court can afford no remedy. There it was thought that mere frustration was insufficient to show that plaintiff had an interest in the property. This is not necessarily an indication that plaintiff would have failed in a tort action. So in the case of frustration of the execution of a zerill, a constructive trust should be imposed upon the wrongdoing beneficiary for the same reason. ${ }^{94}$ In the case of the suppression, spoliation or destruction of a will, the wrongful act may occasion the probate of an earlier will no longer expressive of the testator's intent. Or it may cause an apparent intestacy, thus favoring the heirs.

In England it was once decreed that plaintiff, on proof of his claim in equity, should hold and enjoy the estate until the suppresser should produce the will. Thus, probate was not a necessary preliminary. ${ }^{95}$ In case probate is still possible, that should be the procedure, ${ }^{96}$ but it does not follow that if probate is no longer possible, there is no alternative remedy. Probate may be impossible because the defendant has deprived the plaintiff of the proof required to establish a will. This is a wrong involving the plaintiff's loss of evidence

88. Noell v. Wells, I Lev, 235 (K. B. I668).

89. Christianson v. King Co., 239 U. S. 356, 372, 36 Sup. Ct. II4, I2I, 60 L. Ed. 327, 335 ( $19 \mathrm{I}_{5}$ ).

90. 2 Scotr, TRUSTS (I939) §§ 55.I, 55.6, II 4 , and 3 id. $\$ 359$.

9I. 2 id. $\$ \$ 55.3,55.4,78$, Ir 3 , and 3 id. $\$ 362.5$.

92. Brazil v. Silva, I8I Cal. 490, I85 Pac. I74 (I9I9) ; Gains v. Gains, 2 Marsh. 609 (Ky, I820) ; Blanchard v. Blanchard, 32 Vt. 62 (I859).

93. Moneyham v. Hamilton, 124 Fla. 430 , 168 So. 522 (1936).

94. Thomas v. Briggs, 98 Ind. App. 352, I89 N. E. 389 (1934) ; Dixon v. Olmius, I Cox Eq. 4I4 (I787). See 3 Scotr, TRUSTS (I939) \$ 489.4. Cf. Dye v. Parker, I08 Kan. 304, I94 Pac. 640, I95 Pac. 599 (I92r) (prevention of making a legacy).

95. Hampden v. Hampden, 3 Brown 550, I E. R. I492 (H. L. I709); Dalston v. Coatsworth, I P. Wms. 731, 24 E. R. 589 (Rolls Ct. I72I) (without probate, the heir required to assign for benefit of the plaintiff). For similar action in New Jersey, see Bailey v. Stiles, I Green 220 (N. J. Eq. I839), and in Vermont, Mead and Langdon (IS34), referred to in Adams v. Adams, 22 Vt. 50, 59 (I849); Blanchard v. Blanchard, 32 Vt. 62 (1859).

96. Thayer v. Kitchen, 200 Mass. 382, 86 N. E. 952 (I909) ; Davis v. Seavey, 95 Wash. 57, I63 Pac. 35 (I9I7). 
and a tort remedy should be available. ${ }^{97}$ This remedy constitutes no attack upon the probate decree. ${ }^{98}$ An essentially different cause of action is stated in the complaint. The plaintiff may even recover costs and expenses arising from the additional burden cast upon him in proving the will, due to the defendant's wrongful act. ${ }^{99}$ Perhaps the action for costs could sound either in tort or in contract if it were brought separately.

The plaintiff misconceives his remedy when he seeks to have a will set up in equity. ${ }^{100}$ Yet, while the plaintiff cannot have probate in equity, ${ }^{101}$ it does not follow that he could not have an action in tort because of his loss of evidence, which loss made probate impossible. That in such case he would have a tort remedy in Ohio is implied also from Seeds $v$. Seeds, ${ }^{102}$ where that remedy is made available in the case of the probate of a forged will. Ohio holds, however, that a trust remedy is not granted in the case of a claimant not an heir under an unprobated will. The question whether a tort action could be had was not raised. There was no intimation, however, that such an action would be a collateral attack upon a decree probating a fraudulent will.

Where a revoking will was suppressed, the United States Supreme Court allowed a bill in equity for discovery and accounting respecting the earlier will. ${ }^{103}$ Probate was held unnecessary, probably because it was impossible to prove the suppressed will. It is not clearly stated, however, that the primary wrong to plaintiff was the destruction of evidence. If the one obtaining wrongful probate is in some measure a fiduciary, there exists an independent ground for creating a trust. ${ }^{104}$

The present argument points to the conclusion that interferences with benefits reasonably to be expected from decedents' estates, where the circumstances are susceptible of proof persuasive to a jury, are, after all, indistinguishable from interferences with prospective advantages in business relations and other types of cases. If there has been a prior probate proceeding, however, it cannot be collaterally attacked. This prior proceeding explains the quandary of the court in the case of Broderick's Will. ${ }^{105}$ In general the probate court cannot deal with the problem of damages where a decedent has been restrained from

97. Creek v. Laski, 248 Mich. 425, 227 N. W. 817 (1929); Dulin v. Bailey, I72

N. C. 602 , go S. E. 689 (I916).

98. Dulin v. Bailey, I72 N. C. 608,90 S. E. 689 (I916).

99. Taylor v. Bennett, I Ohio C. C. 95 (I885).

I00. Morningstar v. Selby, I5 Ohio 345 (I846).

IOI. McDaniel v. Pattison, 98 Cal. 86, 27 Pac. 65I, 32 Pac. 805 (1893).

I02. II6 Ohio St. I44, I56 N. E. I93 (I927).

103. Gaines v. Chew, 2 How. 6rg, II L. Ed. 402 (U. S. 1844).

ro4. Segrave v. Kirwan, Beat. I57 (Ir. Ch. I828).

I05. 2 I Wall. 503, 22 L. Ed. 599 (U. S. I874), cited at page I90 supra. 
making a will benefiting the plaintiff, or has been prevented from revoking or altering a will already made or has been denied the right to revoke or alter it. In the case of fraudulent inter-vivos conveyances having a similar effect, no issue can arise respecting an attack on the probate decree and nothing stands in the way to prevent the recognition of the interference as a wrong. On the other hand, probate courts generally can refuse probate to fraudulent or forged wills and can give relief where proper proof is produced that a will has been suppressed or despoiled save where the plaintiff has been deprived by the defendant's act of the evidence necessary to establish it. In cases where the raising of a constructive trust is appropriate, it is difficult to see why an alternative remedy in tort generally should not exist. A probate decree should be held void where the injured claimant has had no opportunity to be heard due to the fraud of the proponent. This situation has often been said to illustrate the so-called extrinsic fraud. In the case where no relief is given, the fraud is often called intrinsic, affecting, as it does, the issues involved and the proof of them. 